\title{
Word in Action. \\ Democracy and Deliberation in Literary Practice in Polish Renaissance
}

\begin{abstract}
Meller Katarzyna, Word in Action. Democracy and Deliberation in Literary Practice in Polish Renaissance. "Poznańskie Studia Slawistyczne" 17. Poznań 2019. Publishing House of the Poznań Society for the Advancement of the Arts and Sciences, Adam Mickiewicz Univesity, pp. 117-126. ISSN 2084-3011.
\end{abstract}

This paper synthesizes relations between Polish democratic system and literary practice in the $16^{\text {th }}$ century. The paper analyses phenomena that project social practice of deliberation on what is important to the community, including political community, and are rooted in the idea of noble democracy - idiosyncratic, mixed political system. The author focuses her interest on the idea of concordia. Consensualism was achieved through debates, political disputes or agons. Deliberative culture also encouraged other distinctive literary forms such as dialogs (political dialogs), polemical treatises, speeches or political satires. The paper underlines the significance of the Protestant Reformation to the Polish Renaissance culture, which introduced modernising tendencies and which expressed the ambitions of influence, participation, public activity, and co-deciding about the community. It stimulated modern way of thinking and shaped the model of discursive society and democratic Church.

KEYwords: Renaissance literature in Poland; democracy and literary culture; rhetoric and political reality

The artifacts of Polish Renaissance culture offer various perspectives on how a fully developed democracy was observed, though between the $15^{\text {th }}$ and the $18^{\text {th }}$ centuries democracy only applied to nobility, i.e. $10 \%$ of the society.

Numerous texts represent the so called occasional, political literature, from elegant, humanist, Latin poesy (odes, epodes, epithalamia) to orations, letters, prosopopoeia, lampoons. They reflected vividly and in different tones various aspects of social life in Polish politeia. Those, however, are not being discussed here. I want to show those phenomena that 
project social practice of deliberation on what is important to the community, including political community, and are rooted in the idea of noble democracy in idiosyncratic, mixed political system of the Polish Republic (Cf. Grześkowiak-Krwawicz, 2011; 2018; Pietrzyk-Reeves, 2011, 15-50; 2012).

Let us remember: regnum commixtum was formed by three states that constituted the sejm or parliament: the king representing the majesty and consistency of the state (monarchy), the senat, the upper house (pragmatic secular and cleric aristocracy), and the lower house (idealistic and ideological deputies, defending the axiology of its state). The latter constituted of the representatives of all the lands of the Respublica Polona, elected by local parliaments and bounded by specific voting instructions. Those provincial assemblies were efficiently operating self-governments organizing life of a powiat (district). They were vital element for forging the responsibility for the state as a whole and for the most immediate area, especially when the central administration was lacking in capacity.

What bounded the system together was consensual decision-making: such an enormous country, culturally and religiously diverse would not function otherwise. Freedom and equality of all the members and lands of the Commonwealth constituted concord (concordia) as the paramount political idea and pragmatic rule (Ekes, 2001, 67-120). For the very reason, concord was a recurring theme of many literary works. Zgoda by Jan Kochanowski stemmed from real political disputes. It did not only discuss the Executionist movement, but also called for compromise in the name of common good (Cf. Krzywy, 2008; Raszewska-Żurek, 2016, 446-449; Płachcińska, 2018, 27-61).

Enemies to the Commonwealth did not put faith in their own strenght but in Polish discord. Kochanowski's work was presented as a discourse, according to the rules of classical rhetoric. And its objective was to persuade, drive and encourage, or, as Aristotle put it, arrive at concord, for only this could settle arguments and resolve issues. Arriving from discord to concord, introducing order into human matters, in political, moral or everyday issues, has a specific symbolic value to Polish Renaissance culture. Politically active nobility amongst the citizens the Commonwealth widely believed that res publica must be equated with communitas (community) (Grześkowiak-Krwawicz, 2017, 88-95). 
Lex regnat, non rex. Those laws bounded the community together. Political and civic capacity was incorporated in how Aristotle defined a person and a state. It was the foundation for theoretical dissertations on state, the topos of political writings and moralistic literature. Consensualism was achieved through debates, political disputes or agons. Polish democratic system at that time assumed that an individual cannot be detached from its society and those who intentionally shy away from political activity were considered useless, particular, self-centered and despicable.

Almost all middle noblemen were supporting the Executionist movement in the $16^{\text {th }}$ century (enforcement of the laws and execution of property; n.b. the followers of the movement supported the Reformation) thus shaping the representative democracy. Also higher nobility, more ambitious, wealthier and better educated, were culturally active.

Literary communication was exclusive between social classes and it will not be discussed here. However, when it comes to democratic systems, we must stress the fact that during Renaissance, politically engaged nobility and its value system shaped the content and form of public debates, giving the culture, in general, but literature in particular, its distinctive character.

Public speaking was supported by the expansion of the vernacular language which was the evidence of the pro-democratic tendencies in $16^{\text {th }}$ century. Not knowing Latin did not prevent from participating in neither political or religious forum nor culture. This leads us to conclusion that public speaking, principally speaking in parliament, is considered the most characteristic for the Polish Renaissance literature. Noble speakers shared humanistic, rhetorical education that resulted in articulate, exemplary citizen (Cf. Axer, 1996; 2010; Borowski, 1990, 415-428; Brzeziński, 2007, 97-106; Płachcińska, 2004).

Orations were political matters, expressions of democracy, freedom of speech as well as performative acts forging ideas, demeanor and political decisions. The country was considered common good and power was subordinate to law and society as the result of equality of law and respect for it. Republican government found expression and support in unhampered debates at regional councils and in parliament sessions (sejm). Parliamentary speech, as a form of political activism, is a testament to the art of the spoken word and the art of political sophistication. The form of oration 
was also chosen by political writers (such as Modrzewski, Orzechowski). Deliberative culture also encouraged other distinctive literary forms such as dialogs (Mikołaj Rej, Marcin Bielski, Stanisław Orzechowski, Augustyn Rotundus, Jan Dymitr Solikowski), a satirical parody of parliamentary debates (Marcin Bielski: Sejm niewieści), votum (senator's speech).

Jan Kochanowski's Odprawa postów greckich (The Dismissal of the Greek Envoys), humanistic tragedy on the immediate cause for the Trojan War, demonstrated how parliamentary speaking reflected the quality of the Trojan political system. The key decision (whether to return Helen to the Greeks) is taken at a council, where equal citizen can all express themselves and convince each other in course of free discussion.

Kochanowski indicates how effective such decision making process can be. However, speech by Iketaon that wins others over advises caution in reaching agreement through democratic discussion. Iketaon, demagogue as he is, intentionally advocates individual's advantage over common good. Kochanowski asks if unhindered freedom of speech is indeed the system's greatest value. What is the true power of word? Such considerations must have led to the increased respect towards protecting the democratic system of the Commonwealth: laws, statutes, social control over parliament (representatives). The public was also relieved that the Polish ruler was not as incapacitated as Priam, in fact Sigismund II Augustus was very much involved in parliamentary decision making process. Iketaon's sophistic speech contradicts Polish Renaissance public speaking that was oriented on rational persuasion. Demagogues were present at local councils, rallies or gatherings, not in parliament where the decisions were being taken in fact (Płachcińska, 2006, 203-228).

The role of the Reformation ideas is a different matter.

The shape and course of Reformation in Poland was intertwined with the country's democracy. Simultaneously, Polish Reformation in the $16^{\text {th }}$ century helped shaping political system of the Polish respublica. For the Reformation introduced modernizing tendencies and it went hand in hand with the ambitions of influence, participation, public activity, and codeciding about the community. It stimulated modern way of thinking and shaped the model of both discursive society and democratic Church.

The historian of culture must note that the Reformation introduced into public discourse not only confessional and ecclesiastical matters but also 
issues crucial to the quality of political and social life (Maciuszko, 1997, 71-82). Let me mention some of them: the unity in faith as the unity of communication, primacy and authority of the Holy Bible which became the source of all the arguments, individual subjectivity and responsibility connected with religious self-consciousness (confession which was inherited in the context of tradition became then the object of critical thinking and then individual choice), using printed books (also religious) as the media in social communication and basis of individual creed, impulse for literacy and new pedagogy, the value of linguistic competence, the authority of consensus, primacy of discourse or debate, conciliation, pluralism and ecclesiastical egalitarianism, dialectics of secular system and the system of salvation, category of individual conscience (and not that of command or social norm) combined with ethical attitude, the ethics of duty, and ethos of independent thinking (the example/model of a self-reliant and responsible person, whose acts are ethical and spring from rational sources) (Zieliński, 1997; Milerski, 2000). The discussion of how those values worked in different texts would result in a very intense study!

The Reformation was pervading to Poland from the 1540s., but was defining its doctrinal aspect up to 1570, in the course of clashes of influences and notions. A historian of culture and literature takes a closer look at how Christian latinitas transforms under the influence of the general values of the Renaissance humanism and Reformation pietas on the local Polish ground, peripheral, though still within the Latin world. What is more, they also observe how, in the multidimensional Polish culture, the pietas litterata of religious, spiritual, ethical and esthetical values develops to form the phenomenon of the Polish version of Christian humanism. The followers of the idea of emendation represented antipapal views and adopted the most general principles of the reformed denomination, synthesizing the elements of the ideas originating from Geneva, Wittenberg and Moravia and from the Christian humanism disseminated of Desiderius Erasmus Rotterdamus. Moreover, the mediatory, conciliar tendency was strong in Poland (Sandomierz agreement, Warsaw confederation). A national ecumenical council was to be convoked, at which John Calvin was supposed to be mediator, but even this did not settle the question of the direction of the confessional evolution. As a result of Jan Laski actions, attempts were made to unite the denominations and to present a common creed. In 
the atmosphere of the confessional pluralism and conciliatory spirit, the boundaries of the creed were blurred (laic members, popular religious literature). We can note a kind of paradox: the beginnings of the Calvinism in Poland were marked with a spirit of mediation, with the ideas of convoking a council, but then the fate of the Polish Calvinism was determined by the split in the very Swiss community. This split was based on a separation of Polish Brethren (as a result of rejecting the baptism of infants, questioning the Trinitarian dogma and arguments over Jesus Christ's divinity).

The notion of humanitas embraces a specific language awareness springing from the rhetorical concept of vir bonus dicendi peritus. Language is a tool of persuasion with which a rational and good person (vir bonus christianus, shepherd, new apostle) shapes a new (or old as referring to the apostolic times) Christian ethos. Rhetoric is anthropology, an optimistic anthropology. It assumes that a reasonable man can be easily persuaded to do good which indicates its freedom and common sense. The art of word can only bloom in the free world as it is the symbol of freedom. The old Polish gentry-democracy, the freedom of speech and religious tolerance proudly enabled those ideas to come into life.

In multidenominational Poland, the controversies between Catholics (Jesuits mostly), but above all with Antitrinitarianists (Arians), obliged the language to express the theological questions in a precise way. Thus, they exercised in rhetoric and public dispute. A similar situation had place on the political stage during the sejm sessions and regional councils. Colloquia were the true theater of speeches, addresses and orations. Their counterparts in the writings were dialogues and quasi-dialogues. They presented opposite, separate views. Those written polemics compiled into long series of attacks, defenses, reprises of the topic, etc. They are characterized with a high culture of disputes, thorough argumentation reaching to the Bible and to the Church Fathers writings, as well as rhetorical means of persuasion. Nevertheless, they also made use of invective, satire and mystification. The most avid Calvinist polemicists were Marcin Krowicki, Paweł Gilowski, Grzegorz of Żarnowiec, Krzysztof Kraiński. They conducted their disputes with both Catholics (with Jakub Wujek, Hieronim Powodowski, Kasper Wilkowski) and Antitrinitarianists (such as Marcin Czechowic or Jan Niemojewski). The objects of the argument were differences in doctrine, sacraments, questions of cult and iconoclasm. 
The expressiveness of the Swiss doctrine and the resolute attitude of theologians and ministers did not interfere with unite action. As a result of Jan Łaski actions, attempts were made to unite the denominations and to present a common creed. An example for such endeavors was the short lived Union of Koźminek in 1555, with Bohemian Brethren [Unity of the Brethren], Sandomierz Agreement 1570 (also with Lutherans) and Warsaw Confederation later on (1573).

The circulation of ideas, exchange of thought, freedom of speech and confession were the means to form an autonomous, individual human being. Not without the help of the printed word though. It enabled spreading the new ideas. Polemics with adversaries were conducive to integration of Protestant believers by the means of common texts (Maciuszko, 2013, 221-244).

The abundance of writings had its consequence in strictly linguistic matters. The claims for introducing national languages to liturgy, the Bible translations and a widespread catechesis resulted in boom of writings in Polish language. Catholics consistently defended Latin as the language of Church, theology and religion. Polemics in writing and books on doctrine demanded a new precise language for religious discourse. The most significant changes in language can be observed at the level of vocabulary theological notions, ritual expressions, names (Winiarska, 2004, 134-320). Many writers were aware of the fact that the language is imminent element for human nature. It was a humanistic axiom. Mikołaj Rej underlined it the most emphatically in his own writer's idea, writer, who diagnoses and treats the public, social and human organisms with linguistic tools (Kacprzak, 2007, 94-106; Maciuszko, 2002). Language reflecting the state of civilization and spiritual development in a national good integrating the community. It needs to be protected and cultivated. Because of this argument Jan Mączyński, lexicographer and a disciple of Filip Melachton, published in 1564 a great, humanistic Lexicon latinopolonicum. Also, Piotr Statoriusz, disciple of T. Beza in Lausanne, published in 1568 Polish language grammar Polonicae gramatices institutio, in eorum gratiam qui eius linguae elegantiam cito et facile addiscere cupiunt. Whereas, Salomon Rysiński was the author of the first compilation of the Polish proverbs (1618). All of the mentioned above were Calvinists.

Polish language was praised as much as Latin was. Any literature 
historian knows how it evolved in the $16^{\text {th }}$ century, how it developed its means of artistic expression. Mikołaj Rej and transformation of his writings, from satirical dialogues to biblical translations and didactical works of an evangelical ethics profile, can be an example of this process. Also the Reformation with its education towards Christian humanity initiated writing in national languages. Christianitas followed humanitas, which recognized vernacular language as a mean to reach its ideals (Otwinowska, 1974, 119-270).

What were the characteristics of Calvinism on the periphery, on the outskirts of the Latin world, the Christian latinitas? As a religious doctrine it remained a minority creed, whereas interpreted as cultural values it became a great intellectual adventure. It seems that the power of the doctrine was weaker in relation to its Genevan root because it was never fully adopted. First and foremost the predestination doctrine was rejected as inconsistent with the idea of moral perfection and quest for virtue, which was very close to the Renaissance moralistic writers. Another specific trait of the Polish Reformation was the selective reception of different theologians. The most was taken from Melachton, Desiderius Erasmus of Rotterdam, less from Martin Luther, John Calvin, Huldrych Zwingli, Martin Bucer. This eclecticism, via media may be a characteristic for the remote doctrinal periphery.

The inspiring role of Protestantism consisted in expanding the area of the intellectual investigation, the vital ideological varietas and pluritas, and in deepening the dialectical agility, linguistic and rhetorical dexterity, in enriching the literary experience. Christian humanitas enriched the general repertoire of values with its own reflections and experiences on freedom, tolerance, dignity, concord, simplicity and so on. It also improved the tools of the critical mind (philology, rhetoric, history) and social skills (denominational concord), intellectual (theological speculations, biblical hermeneutics, the art of spoken and written word).

\section{References}

Axer, J. (1996). Trening oratorski jako składnik wychowania obywatelskiego w systemie republikańskim. Przypadek polski. In: Retoryka antyczna i jej dziedzictwo. Red. M. Grzesiowski. Warszawa: Fundacja Aletheia - Polskie Towarzystwo Filologiczne, pp. 39-51. 
Axer, J. (2010). Kultura polska z punktu widzenia mechanizmów recepcji tradycji antycznej. Prolegomena do syntezy. In: Humanistyczne modele kultury nowożytnej wobec dziedzictwa starożytnego. Red. M. Prejs. "Humanizm polski. Syntezy” t. 5. Warszawa: Wydawnictwo Neriton, pp. 15-82.

Borowski, A. (1990). Wymowa sejmowa $w$ Polsce $w$ latach 1550-1584. In: Cracovia litterarum. Kultura umysłowa i literacka Krakowa i Małopolski w obie renesansu. Księga zbiorowa Między-narodowej sesji naukowej w czterechsetlecie zgonu Jana Kochanowskiego (w Krakowie 10-13 X 1984). Red. T. Ulewicz. Wrocław: Ossolineum, pp. 415-428.

Brzeziński, S. (2007). Kultura polityczna w świetle języka. O senacie i senatorach na sejmach Zygmunta Augusta. In: Nad społeczeństwem staropolskim. T. 1: Kultura-instytucje-gospodarka w XVI-XVIII stuleciu. Red. K. Łopatecki, W. Walczak. Białystok: Ośrodek Badań Europy-Wschodniej - Uniwersytet w Białymstoku, pp. 97-106.

Ekes, J. (2001). Trójpodziat władzy i zgoda wszystkich. Naczelne zasady "ustroju mieszanego” w staropolskiej refleksji politycznej. Siedlce: Instytut Historii Akademii Podlaskiej.

Grześkowiak-Krwawicz, A. (2011). Noble republicanism in the Polish-Lithuanian Commonwealth (an attempt at description). "Acta Poloniae Historica" 103, pp. 31-65.

Grześkowiak-Krwawicz, A. (2017). Rzeczpospolita - państwo czy wspólnota. Zmiany $w$ systemie wartości $w$ dyskursie politycznym XVIII $w$. In: Wartości polityczne Rzeczypospolitej Obojga Narodów. Struktury aksjologiczne i granice cywilizacyjne. Red. A. Grześkowiak-Krwawicz, J. Axer. "Kultura Pierwszej Rzeczypospoitej w dialogu z Europą” t. 3. Warszawa: Wydawnictwo Uniwersytetu Warszawskiego, pp. 88-116. Grześkowiak-Krwawicz, A. (2018). Dyskurs polityczny Rzeczypospolitej Obojga Narodów. Pojęcia, idee. Toruń: Wydawnictwo UMK.

Kacprzak, M. (2007). "Niech kamienie woła... Mikołaj Rej o roli literatury, pisarza $i$ własnej twórczości. In: Mikołaj Rej w pięćsetlecie urodzin. Studia literaturoznawcze. Red. J. Sokolski, M. Cieński, A. Kochan. Wrocław: Oficyna Wydawnicza ATUT, pp. 94-106.

Krzywy, R. (2008). Sztuka wyborów i dar inwencji. Studium o strukturze gatunkowej poematów Jana Kochanowskiego. Warszawa: Wydawnictwo IBL.

Maciuszko, J.T. (1997). Od reformy do Reformacji. In: Kościoły, wspólnoty, herezje. Szkice z tradycji chrześcijańskiej. Red. M. Dobkowski. Warszawa: Wydawnictwo Naukowe Semper, pp. 71-82.

Maciuszko, J.T. (2002). Mikołaj Rej. Zapomniany teolog ewangelicki z XVI wieku, Warszawa: CHAT.

Maciuszko, J.T. (2013). Socjohistoryczne przesłanki rozwoju piśmiennictwa ewangelickiego $w$ Polsce XVI-XVIII w. In: Kościoty luterańskie na ziemiach polskich (XVI-XX w.). T.1. Red. J. Kłaczkow, Toruń: Adam Marszałek, pp. 223-244.

Maliszewski, K. (2001). Komunikacja społeczna $w$ kulturze staropolskiej. Studia $z$ dziejów kształtowania się form i treści społecznego przekazu w Rzeczypospolitej szlacheckiej. Toruń: Wydawnictwo UMK. 
Milerski, B. (2000). Wartości kulturowe protestantyzmu. "Kalendarz Ekumeniczny" t. 1. http://biblioteka.teatrnn.pl/dlibra/Content/8985/Wartosci_kulturowe_Protestantyzmu.pdf. 6.10.2015.

Milerski, B. (2012). Pedagogiczne dziedzictwo protestantyzmu. "Gdański Rocznik Ewangelicki” t. 6, pp. 189-196.

Otwinowska, B. (1974). Język-naród-kultura. Antecedencje i motywy renesansowej myśli o języku. Warszawa: Wydawnictwo IBL.

Pietrzyk-Reeves, D. (2011). Podstawy wspólnotowego ładu Rzeczypospolitej w XVI wieku a wplyw humanizmu i republikanizmu. In: Polska czyli... Idee wspólnoty politycznej i tożsamości narodowej w polskiej tradycji intelektualnej. Kraków: Ośrodek Myśli Politycznej. [In English: https://www.academia.edu/23957662/The_Foundations_of_Rzeczpospolita_in_the_16th_Century_and_the_Influence_of_Humanism_and_Republicanism].

Pietrzyk-Reeves, D. (2012). Ład rzeczypospolitej. Polska myśl polityczna XVI wieku a klasyczna tradycja republikańska. Kraków: Księgarnia Akademicka.

Płachcińska, K. (2000). Wizja społeczeństwa demokratycznego w mowach sejmowych z czasów Zygmunta Augusta. (Zarys problematyki). In: Od średniowiecza ku wspótczesności. Red. J. Okoń. Łódź: Wydawnictwo UŁ, pp. 244-249.

Płachcińska, K. (2002). Doskonatość słowa na straży doskonałości ustroju - z mów sejmowych w czasach Zygmunta Augusta. In: O doskonałości. Cz. 2. Red. A. Maliszewska. Łódź: AWŁ.

Płachcińska, K. (2004). Obraz kultury retorycznej społeczeństwa szlacheckiego na podstawie mów sejmowych z lat 1556-1564. Łódź: Wydawnictwo UŁ.

Płachcińska, K. (2006). Oracje z "Odprawy posłów greckich” w świetle mów sejmowych z czasów Jana Kochanowskiego. "Pamiętnik Literacki" 97, 4, pp. 203-228.

Płachcińska, K. (2018) "Swój urząd czynić”. Profil obywatelski twórczości Jana Kochanowskiego. Łódź: Wydawnictwo UŁ.

Raszewska-Żurek, B. (2016). Zgoda w rozumieniu Polaków czasów staro- i średniopolskich. Warszawa: Instytut Slawistyki PAN.

Winiarska, I. (2004). Stownictwo religijne polskiego kalwinizmu od XVI do XVIII wie$k u$. Warszawa: Semper.

Wojak, T. (red.) (1970). Wktad protestantyzmu do kultury polskiej. Z zagadnień protestantyzmu w Polsce. Warszawa: Wydawnictwo "Zwiastun".

Zieliński, T.J. (1997). Protestancka alternatywa. Ewangelicyzm polski jako oferta spoteczna. "Myśl Protestancka" nr 1, pp. 31-38. 